\title{
O medo da arte: como a censura se torna iconoclastia
}

\author{
David Freedberg'
}

\section{Tradução: Felipe da Silva Corrêa"}

Resumo: Todo ato de censura é também um ato de iconoclastia. Juntos eles constituem um dos mais antigos paradoxos da fabricação de imagens e da figuração. Fabricar uma imagem é tanto querê-la quanto temê-la. Quanto mais ela é desejada, mais ela parece contra naturam, e logo é temida. Frequentemente ela tem uma vitalidade contrária a sua materialidade e seu conceito. Analisar episódios individuais de censura e iconoclastia é desvelar as raízes tanto do medo das imagens quanto do medo da arte. Contudo, cada um dos vários motivos para censura e iconoclastia é um testemunho, acima de tudo, da impossibilidade de escapar deles.

Palavras-chave: Censura. Iconoclastia. Medo da arte.

\section{The Fear of Art: How Censorship Becomes Iconoclasm}

\begin{abstract}
Every act of censorship is also an act of iconoclasm. Together they constitute one of the oldest paradoxes of imagemaking and figuration. To make an image is both to want it and to fear it. The more it is desired, the more it seems contra naturam, and so is feared. It often has a vitality that is startlingly at odds with both its materiality and its concept. To parse individual episodes of censorship and iconoclasm is to uncover the roots of both the fear of images and the fear of art. But each of the many motives for censorship and iconoclasm testify, above all, to the impossibility of escaping it.
\end{abstract}

Keywords: Censorship. Iconoclasm. Fear of art.

\footnotetext{
I David Freedberg é mais conhecido por seu trabalho sobre respostas psicológicas à arte e, particularmente, por seus estudos sobre iconoclastia e censura. Professor de história da arte e diretor da Italian Academy for Advanced Studies in America na Universidade de Columbia. Foi diretor do Warburg Institute entre os anos de 2015 e 2017. Casa Italiana, 1161 Amsterdam Avenue, New York, NY 10027. ORCID: https://orcid.org/0000-0003-1655-6989. Nova York, EUA.
} financiado pela Fundação de Amparo à Pesquisa do Estado de São Paulo (FAPESP), processo n 2017/14530-2. Aluno no Instituto de Filosofia e Ciências Humanas (IFCH) da Unicamp, rua Cora Coralina, 100. Cidade Universitária Zeferino Vaz, Barão Geraldo. Campinas -RJ 13083-896. ORCID: https://orcid.org/0000-0001-6214-5537. ID Lattes: 3067645039264977. São Paulo, Brasil. 
Todo ato de censura é também um ato de iconoclastia. Juntos eles constituem um dos mais antigos paradoxos da fabricação de imagens e da figuração. Fabricar uma imagem é tanto querê-la quanto temê-la. Quanto mais ela é desejada, mais ela parece contra naturam, e logo é temida. Frequentemente ela tem uma vitalidade contrária a sua materialidade e seu conceito. Analisar episódios individuais de censura e iconoclastia é desvelar as raízes tanto do medo das imagens quanto do medo da arte.

Todo ato de censura, todo ato iconoclasta fornece pistas do uso social e da função das imagens. Nada ilustra mais claramente as dimensões sociais das imagens do que as histórias de iconoclastia e censura - e, mais particularmente, onde elas se encontram. Elas ilustram poderosamente a junção entre o cultural e o político; mostram como o estético se torna mais social; e como o psicológico e o social se intersecionam em respostas motivadoras às imagens. A transformação de esforços de censura, mesmo que pequenos, em atos mais destrutivos de mutilação, dano e eliminação ilustra claramente como o medo das imagens e da arte conduz nossas relações com a cultura, complicando-as em cada estágio e, ocasionalmente, resolvendo-as.

Mas há um paradoxo subjacente a isto. O medo e o amor pela arte são dois lados da mesma moeda. Investir-se emocionalmente a tal ponto em um objeto é abrir as portas para a decepção, a insatisfação e uma sensação de expectativa frustrada - de onde vêm, por exemplo, os constantes ataques a representações de líderes políticos que não cumprem o que deles se espera, ou a imagens percebidas como sexualmente excitantes, seja na pornografia ou na arte (ou em ambas, quando elas se sobrepõem).

Censurar ou destruir uma obra é comprovar seu poder sobre seu público. É reconhecer seu poder de sedução (seja ele sexual, político ou ambos) e admitir que o que não deveria ter poder, na verdade tem. É a tentativa de assegurar que o material morto, ou o produto de uma mão há muito tempo morta, não possa ser percebido como dotado de vida e animação. Frequentemente isto pode ser visto com diferentes graus de ansiedade implícitos ao agravamento da hostilidade em relação a uma obra, desde o ajuste ou supressão de alguns de seus elementos superficiais até a excisão física e obliteração.

A história das imagens é possivelmente a história de sua habilidade de incitar amor e medo. Como diz o antigo topos, elas tornam presente o ausente (como foi famosamente dito no tratado fundamental de Alberti sobre a pintura do Renascimento em 1435). No caso dos atos de antipatia, sua ha- 
bilidade de fazer presente uma pessoa odiada (seja por incorporação ou por simples truques) é ainda mais gritante. $O$ mero fato de censura e iconoclastia comprova vivamente isto. Repetidamente, o cancelamento e a destruição da imagem idólatrica (qualquer que seja sua concepção) exemplificam a antinomia básica inerente às imagens.

Contudo, os pontos de vista sobre a arte mudaram. Vivemos em tempos nos quais a arte não é mais questão de habilidade manual ou representacional, ou mesmo a produção de um objeto físico. A arte acabou por ser definida pelo grau a que satisfaz uma ideia de arte e pela sua evocação de um estado estético irônico supostamente separado da fisicalidade ou das emoções que ela incita. A reinvindicação implícita e ocasionalmente assaz explícita - é que, precisamente, a obra não está viva (mesmo diante do artifício mimético) e que as emoções, o interesse e o próprio corpo físico são necessariamente excluídos dos julgamentos estéticos sobre ela.

A questão predominante da arte hoje, então, é se ela está fundamentalmente separada do poder das imagens. Subjacente ao medo da arte é a noção de que elas são de alguma forma mais do que arte, de que são aquilo que representam - mesmo no caso de imagem não figurativa - e, consequentemente, perigosas. Embora muitos artistas - talvez mais notável e vulgarmente Jeff Koons - joguem justamente com esta dicotomia, a resposta intelectual e filosófica preponderante é que a arte está separada dos meros efeitos daquilo que representa; e, ainda assim, todo caso de iconoclastia mostra que a obra, mesmo que conceitual, não é mais que a imagem (ou imagem da imagem) que a materializa - mesmo no caso da imagem abstrata. Borrar uma obra abstrata com uma mancha removível é suficiente para mostrar que ela não tem poder duradouro, seja como imagem ou como obra de arte. A partir de tais atos, a noção de arte apenas como ideia leva uma surra.

No fim das contas, aqueles que buscam censurar e destruir arte comprovam seu poder, tanto quando a obra é vista como símbolo de algo odiado ou malquisto, quanto se é vista como um simples recipiente da forma. Qualquer que seja a justificativa dada pelos censores, suas ações desmentem a afirmação de que o status estético da obra de arte seja radicalmente diferente daquele de imagens ou formas de representação mais ordinárias. Mesmo aquilo que é tido como as dimensões puramente formais e estilísticas das obras de arte tem efeitos emocionais e corporais que resistem insidiosamente ao controle tanto externo quanto interno. 
Todas as formas de antipatia em relação à arte fornecem evidências do que ela significa para seus espectadores. Em toda obra de arte há um corpo significativo, uma forma de materialidade que contradiz seu suposto status imaterial ou suas pretensões de transcendência. A obra não existe no reino do espírito puro; ela importuna o corpo. Toda representação, de fato toda representação imaginada, carrega as inescapáveis consequências corporais do olhar (ou, mais precisamente, a ativação do substrato neural das respostas corporais da visão). Quando tais consequências acontecem de formas percebidas como inapropriadas ou indecorosas, os elementos em uma obra que suscitam respostas sensuais, ou que parecem facilitá-las, devem ser removidos, cobertos ou modificados - da mesma maneira como, no século XVI, os críticos das pinturas de Michelangelo na Capela Sistina argumentaram por razões tanto iconográficas quanto estilísticas, ou como na recente visita do presidente do Irã aos Museus Capitolinos em Roma, durante a qual os nus foram escondidos sob caixas (Kirchgaessner 2016). Os censores buscam controlar deste modo a própria arte.

Ninguém duvida das motivações sociais e políticas da iconoclastia e da censura. A maioria das análises enfatiza as dimensões históricas de episódios individuais em detrimento dos fatores psicológicos em reposta às imagens de forma geral. Sempre se pode afirmar - como frequentemente se afirma - que nenhuma resposta psicológica independe de seu contexto histórico de fato, que cada resposta do tipo é um produto de uma formação histórica específica. Todavia, considerando-se a convergência das respostas psicológicas em diferentes contextos, culturas e episódios individuais, uma questão mais complexa pode ser levantada. Ela começa na tentativa de estabelecer como níveis tão básicos de resposta podem ser formulados e continua no exame das formas como eles são modificados pelas particularidades dos contextos social e político.

O argumento fundamental deste artigo - contrário à presente tendência atual, em que visão, ação e repressão são tão insistentemente historicizados - é que apenas uma abordagem deste tipo nos permite entender as reais diferenças entre os episódios individuais. Em outras palavras, para entender as diferenças, é preciso primeiramente buscar identificar as semelhanças, da forma mais responsável e livre de parcialidade e preconceito solipsista possível. Isto envolve o reconhecimento do quanto somos de qualquer modo inclinados a identificar as similaridades antes das diferenças.

O USO DE IMAGENS EM DIFERENTES CULTURAS E LONGOS INTERVALOS DE TEMPO É conduzido por fatores psicológicos profundos que têm suas raízes em 
relações neurais específicas entre visão, movimento e incorporação. São relações especialmente críticas para a iconoclastia, visto que coincidem com muitos dos fundamentos dos medos que os atos iconoclastas demonstram: o medo de que a imagem morta se mova, que os olhos testemunhem os poderes realistas das imagens, que de alguma forma haja um corpo na imagem - mesmo que abstrato.

O que aprendemos da análise do substrato neural de respostas a imagens é que estes medos, registrados ad infinitum ao longo da história da iconoclastia, não são nem vazios, nem supersticiosos e nem ilusórios. São respostas que subtendem diferença. A partir deles aprendemos a entender mais claramente por que a atribuição de capacidades senso-motoras a imagens visuais permanece insistente em diferentes culturas e por que os poderes do corpo nunca deixam de ser atribuídos, contra a razão, à matéria morta (cf. Freedberg \& Gallese 2007). Não é de se espantar que as escrituras de muitas religiões se juntem em seu medo da representação; não é de se espantar que os autores de imagens que parecem vivas sejam considerados blasfemos em sua emulação do que é apenas poder divino; não é de se espantar que este aparente investimento de vida em uma imagem leve à idolatria que tanto provoca os iconoclastas. O iconoclasta busca se assegurar de que aquilo que está morto não tenha chances de ressurreição, seja em corpo ou em espírito, e mostrar que, afinal, a arte não tem os poderes que transcendem ao seu material e que levam à sedução, ao desejo e à veneração.

Estas são atitudes paradigmáticas e exemplares que refletem a mais profunda ontologia das imagens. Elas também permitem um melhor entendimento da diversidade e intensidade de modificações locais da vontade de modificar ou destruir.

Tomemos como exemplo o retrato em xilogravura do grande pensador irênico do período da Reforma, Erasmo de Roterdã, na cópia de 1550 da Cosmographia Universalis de Sebastian Münster, ilustrado na figura 1. Seus olhos foram furados, sua boca rasurada e seu rosto cortado por um grande $X$ duplo. Estas ações foram executadas no retrato com força extraordinária. Se não soubéssemos que foram feitas por um censor - como em qualquer obra de Erasmo ou contendo referências a ele -, pensaríamos que estas marcas, estes esforços de excisão e obliteração, foram feitos por alguém que tinha algum rancor pessoal contra ele (é quase como se elas estivessem atacando pessoalmente o seu ser corporal) ou talvez pelo medo de que a imagem possa ser - ou vir a se tornar - viva. 
Figura 1 Anônimo segundo Hans Holbein, o Jovem. Retrato de Erasmo de Rotterdã, 1550 Xilogravura; desfiguração e inscrição: caneta e nanquim In: MÜNSTER, Sebastian. Cosmographia Universalis. Basileia: Henric Petric. Fotografia do autor.

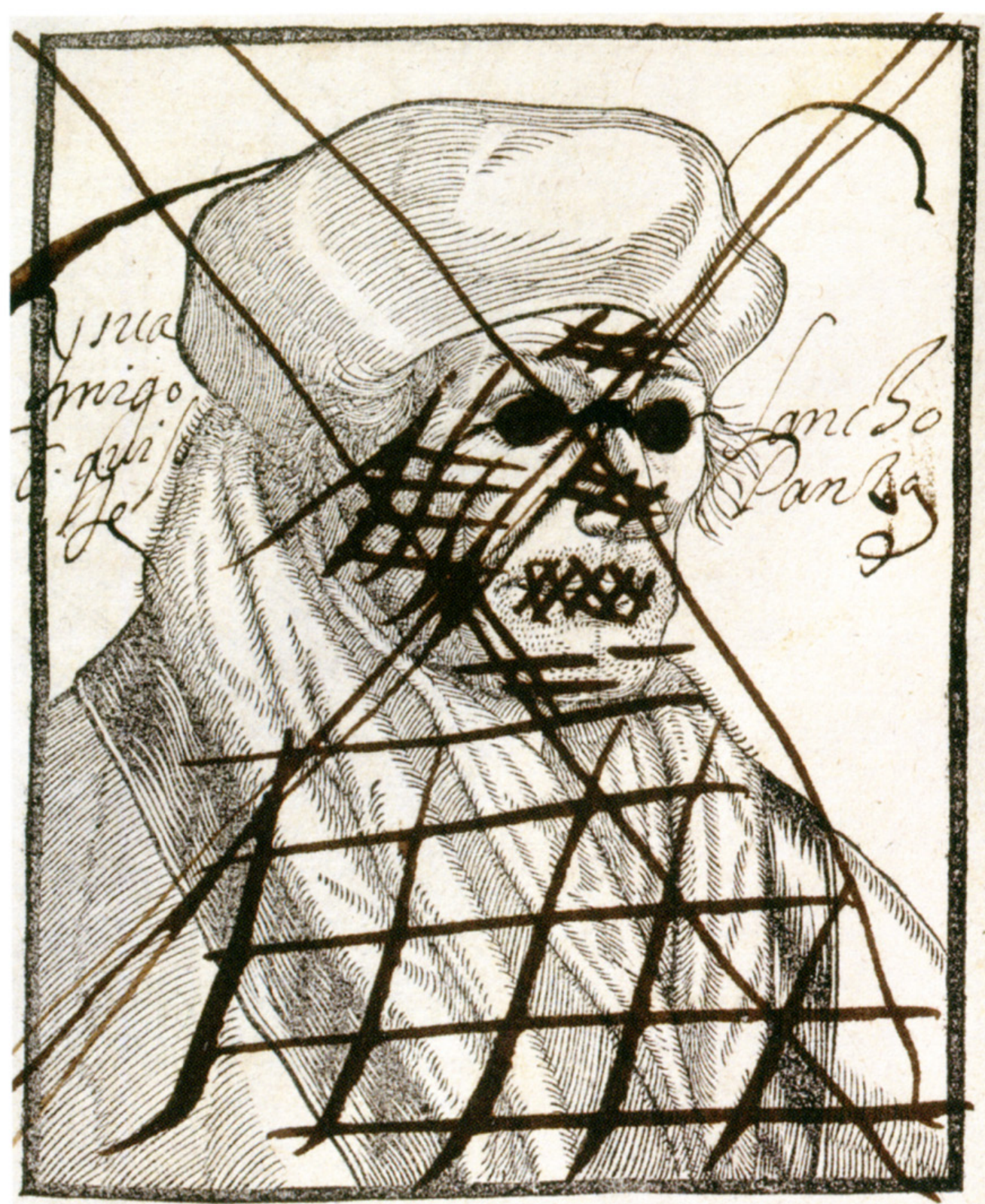

Os censores podem ter rasurado as palavras ofensivas em livros de Erasmo ou de outros autores, mas frequentemente atacar o retrato de alguém parece mais imediatamente contundente que qualquer eliminação da palavra escrita ou impressa. Isto é mais impressionante para seus espectadores, e talvez mais satisfatório para seus agressores, porque é um ataque ao corpo em si - e, neste processo, também afeta visceralmente os espectadores. A xilogravura na Cosmographia de Münster é potente em primeiro lugar, mas seu impacto é fortemente potencializado pela violência do ataque ao rosto. O efeito nos espectadores desta imagem danificada parece palpável. Não se 
trata apenas da sensação que alguém tem daquele ataque em seu próprio corpo, mas da sensação que este alguém tem da força das ações por trás dele.

A rasura no rosto e no torso já são suficientemente chocantes, mas para a maior parte dos espectadores é o furar dos olhos que tem o impacto mais visceral. Estes são modos de censura e ataque ad personam - acima de tudo, a eliminação dos olhos representados e, em menor escala, a obliteração da boca - que ocorrem ao longo dos séculos. É infindável o número de imagens na história da arte e das imagens que foram desaprovadas por alguma razão e que tiveram seus olhos removidos, como que para privá-las exatamente dos indícios de sua vitalidade. A rasura ou excisão visual da boca tem uma motivação psicológica semelhante - selar ou simplesmente renovar o órgão da fala. Em cada caso, os poderes do corpo atribuídos à imagem, os quais Ihe conferem a vida que parece inerente a imagem, devem ser freados e tornados eternamente ineficazes.

É neste contexto dos traços semelhantes da ação em uma imagem e das constâncias psicológicas por eles traídas que podemos entender melhor as diferenças entre o ataque à imagem de Erasmo na Cosmographia de Münster no século XVI e os ataques do século XXI, durante a Primavera Árabe de 2011, nos pôsteres do rei do Barém, ilustrados na figura $n^{\circ}$. 2. As estratégias manuais de censura e cancelamento, bem como os focos de obliteração, não parecem ter mudado muito em quatro séculos e meio.

Em exemplos como estes, é quase como se as ações do censor, seja ele oficial ou não, passassem diretamente por formas muito repetidas de iconoclastia (cf. Freedberg 1985). Obviamente, há diferenças sutis nesta transição e elas são instrutivas. Voltaremos a elas mais tarde.

Figura 2

Pôster desfigurado do rei Hamad bin Isa al-Khalifa do Barém, em protesto na cidade de Manama, Barém, 15 de fevereiro de 2011. Fotografia do autor.

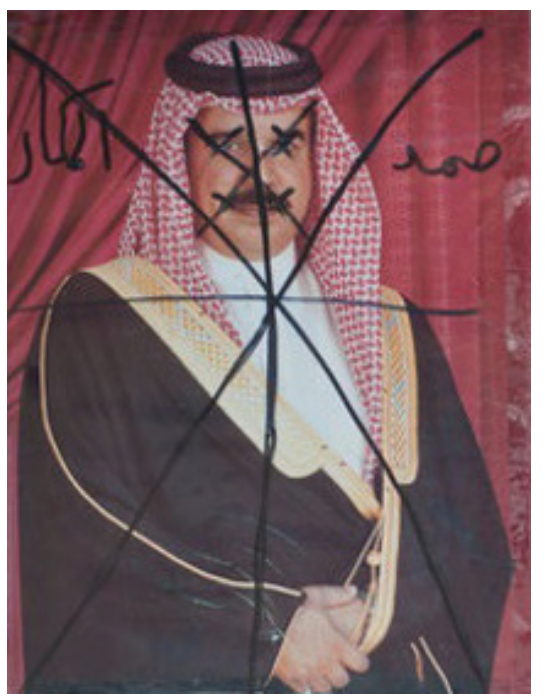


Enquanto isto, observemos uma série de casos de ataques em olhos e às vezes em bocas, nos quais o grau de veemência dos ataques varia significantemente em cada episódio. Mesmo na presente comparação, por exemplo, está claro que a imagem do rei Hamad ibn 'Isa Al Khalifa foi bem menos ferozmente atacada que a de Erasmo, com o furar dos olhos substituído por riscos cruzados leves e a boca quase não tendo sido selada.

A limpeza e restauração de um retrato feito no século XVI por Dirk Jacobsz. representando seu pai, o pintor Jacob Cornelisz. van Oostsanen, e sua mãe, hoje no Toledo (Ohio) Museum of Art, revelaram que esta obra também havia sido atacada nos olhos e na boca. Contudo, os cortes foram relativamente delicados - duas leves incisões para cada olho, uma cruz leve sobre a boca (Toledo (Ohio) Museum of Art 1960, 7). O mesmo aconteceu com o grande martírio de São Cristóvão pintado por Mantegna em uma capela da Igreja dos Eremitas em Pádua (encomendado em 1448 e concluído em 1457), no qual cada um dos olhos da figura principal segurando o pé do santo imolado parecem ter apenas um corte; e isto se repete ainda nos soldados da versão de 1488 do Massacre dos inocentes de Matteo Giovanni no Museo di Capodimonte, em Nápoles. De forma paradoxal e incomum, é como se os iconoclastas, embora desejassem privar os ofensores de sua visão (ou dos traços fisionômicos mais reveladores de sua vitalidade), também reconhecessem o valor da arte nestas obras e, assim, tivessem se privado de um ataque mais vigoroso. Aqui começa a se tornar compreensível novamente a ambivalência que um ato de iconoclastia contém - a ambivalência predominantemente tácita, em tais instâncias, sobre a relação entre o poder da imagem e a qualidade da arte que a produziu.

Porém, na maior parte do tempo, os exemplos são mais violentos. No Políptico das sete obras da Misericórdia de 1504 do mestre de Alkmaar, os olhos do protagonista da cena de Vestindo os pobres foram cortados fora com tamanha veemência que talhos profundos foram deixados no suporte de madeira deste corpo pintado (ver figura 3 aqui, e figuras 16 e 17 em Freedberg 1985). Como o trabalho havia sido restaurado rapidamente - provavelmente pouco tempo depois do ataque - estes efeitos só se tornaram aparentes durante a execução recente de um projeto de conservação, antes que fossem habilmente recobertos.

Estes são, de fato, cortes dolorosos. São ataques ao nosso próprio sentido de incorporação, ataques que nos chocam de maneiras aparentemente inexpli- 
Figura 3

Mestre de Alkmaar. Os sete trabalhos da Misericórdia, detalhe de As roupas dos pobres, s.d. Rijksmuseum, Amsterdã. Fotografia do autor.

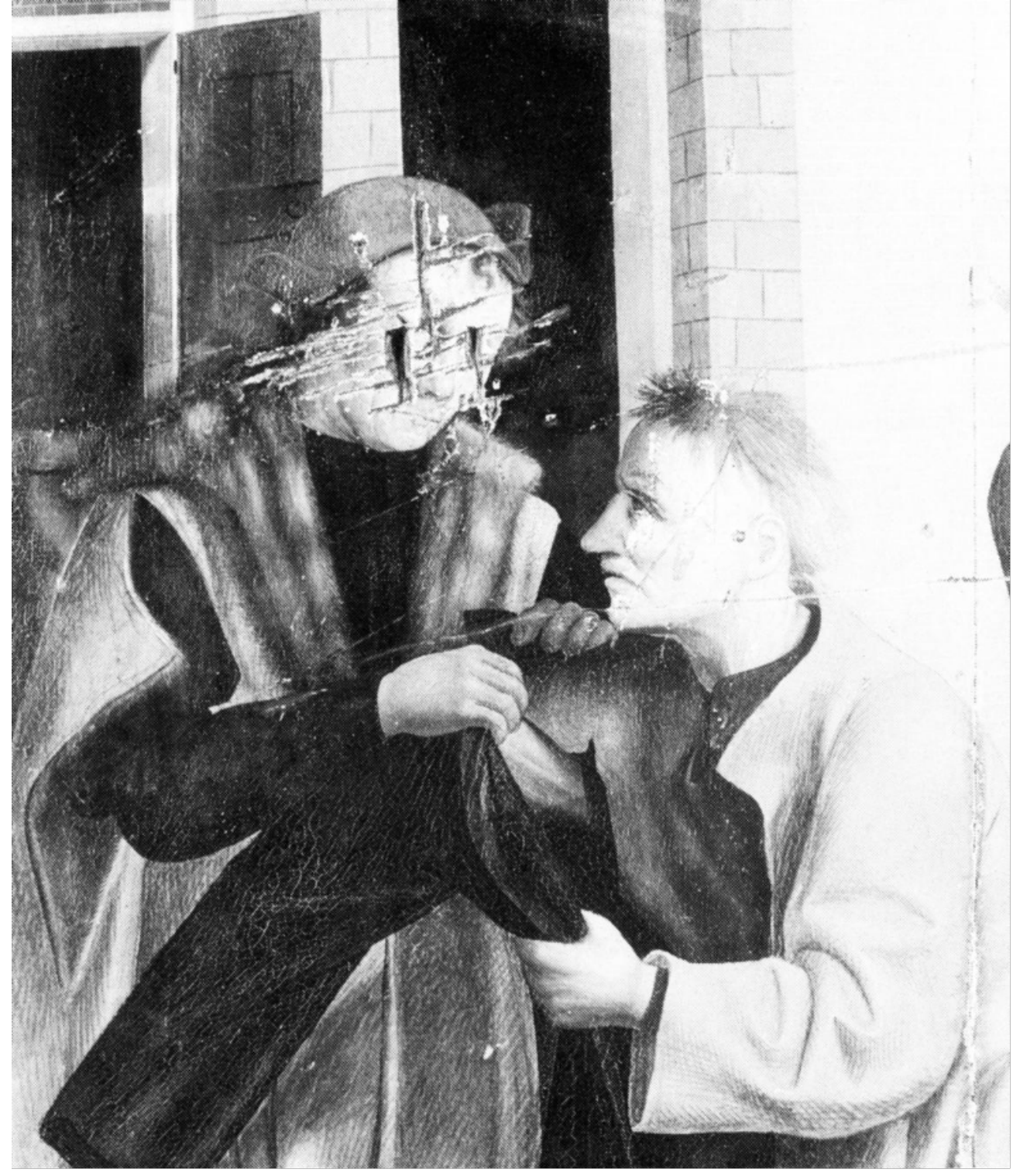

cáveis. Ver o painel com estas feridas, mesmo em uma fotografia, é ter uma grande sensação de choque diante do insulto a ele, de maneira que somos quase levados a querer cobrir os próprios olhos e protegê-los de um destino semelhante, como se nós, espectadores de outro mundo, sentíssemos a ameaça iminente deste exato perigo - de onde, exatamente, não saberíamos. Mas sabemos, ou podemos ao menos especular. Hoje sabemos que algumas topografias corticais ativadas em espectadores de insultos ao corpo alheio são as mesmas que seriam ativadas na realidade, embora obviamente em menor grau. É mais do que provável que as áreas topograficamente relevantes do córtex somatossensorial também sejam provavelmente ativadas com a visão de punções e incisões (ver os experimentos clássicos de Keysers et al. 2004). Repetidamente, censura e iconoclastia comprovam a ameaça que parece advir do pensamento de que há vida - um corpo vivo - em uma imagem feita de matéria morta. Sua habilidade de se tornar viva - ou de ser vivificada - parece inescapável. Subjacente a todos estes atos é o esforço para silenciar a imagem, para deixar claro que ela não está viva e não voltará a falar, ver ou agir. 
Tais atos buscam mostrar que a imagem não deve ser temida já que não é o que parece ser, mas sim aquilo que ela fisicamente é: nem espírito, nem arte, apenas linhas ou formas sobre ou dentro de superfícies inertes. Expor e trazer tudo isto à tona pode exigir um gesto que pode ser frio ou extravagante, casualmente controlado ou violento. Porém, estas tentativas de provar que uma imagem ou a arte não têm os poderes atribuídos a elas raramente alcançam seu objetivo. É por isto que a censura e a iconoclastia são os sintomas mais expressivos do medo da arte.

AS SIMILARIDADES APARENTES ENTRE OS FOCOS E TÉCNICAS DE ICONOCLASTIA E AS motivações psicológicas que eles revelam oferecem as mais marcantes constâncias por toda a longue durée da censura e da iconoclastia. Ao mesmo tempo, na maior parte (senão em todos) os casos, é possível situar respostas tão imediatas, ou melhor, sintomas tão imediatos do medo das imagens, em seus contextos específicos. Porém, é precisamente na dialética entre comportamento habitual, enraizado nas respostas automáticas às imagens, e as particularidades de contexto que começam a emergir as diferenças mais significativas e reveladoras entre os casos individuais.

A Cosmographia de Sebastian Münster, por exemplo, é apenas um dos vários livros de Erasmo ou daqueles em que ele aparece que foram censurados no século XVI, antes mesmo do primeiro Index Librorum Prohibitorum de 1559, a grande lista de livros censurados prestes a serem empilhados e queimados, antecipando os eventos semelhantes do futuro. Tanto famoso quanto notório por ter permanecido católico enquanto simpatizava com noções vistas como demasiadamente próximas dos líderes da Reforma (em particular Lutero), Erasmo constantemente irritou as autoridades católicas com suas interpretações teológicas muito próximas destes limites, embora - ou talvez porque - ele fosse próximo de Lutero, mas tenha finalmente dado um passo atrás quando estava na iminência de se converter abertamente.

O retrato na Cosmographia (fig. 1) teria sido muito forte mesmo se não tivesse sido censurado, mas aqui, com as marcas da obliteração e da excisão tão claramente presentes, ele é ainda mais forte. $O$ ato de apenas o observar é também sentir a agressão por trás do ataque, permitido pela própria autoridade eclesiástica, qualquer que possa ter sido, por vezes, a espontaneidade de tais atos. De fato, ao longo da história da iconoclastia, a fronteira entre as expressões de antipatia espontâneas e deliberadas (ou organizadas) é frequentemente difícil de distinguir, tanto analítica quanto historicamente. 
Muito já foi dito até aqui sobre os olhos como alvo de ações iconoclastas e sobre sua mutilação ou eliminação como forma de lidar com a apreensão e o medo de que a imagem possa estar viva; mas o esforço para selar a boca nesta imagem, como em várias outras, requer mais comentários. Esforços do tipo são frequentemente feitos como se prevenissem o alvo da ação iconoclasta de dizer qualquer outra coisa, de revelar, mutatis mutandis, o verdadeiro eu do orador.

Na época de Erasmo, não havia um topos muito mais comum sobre a relação entre figuras e palavras do que aquele que exortava os espectadores a se lembrarem de que eram os textos do modelo que transmitiam uma imagem melhor dele - "seus textos mostram a melhor parte", dizia a inscrição na famosa gravura de Dürer de 1526 representando Erasmo sentado à sua escrivaninha. Este topos segundo o qual um homem é melhor revelado pelo que ele diz do que pela sua aparência foi adotado tanto por escritores quanto por criadores de imagem ao longo dos séculos.

No século seguinte, quando desafiado a fazer um retrato falar, Rembrandt virou este tema de cabeça para baixo ao mostrar que mesmo uma simples água-forte ou uma pintura poderiam falar (ou pelo menos aparentar fazê-lo). Ao fazer isto, ele mobilizou todos os recursos de sua arte para deixar claro que seu modelo parecesse falar - como notavelmente em seus retratos do pregador menonita Cornelis Claes Anslo (cf. Emmens 1956). Tudo isto, claro, era perfeitamente consistente com a ênfase protestante, de maneira geral, na primazia da palavra sobre a imagem, no logos acima da revelação visual. Não causa espanto, portanto, que o censor e o iconoclasta tenham que se assegurar duplamente de que o órgão da fala foi selado, costurando-o ou mesmo destruindo-o, para que não volte a proferir palavra alguma - de tão profundo que é o medo da operacionalidade em potencial da imagem!

A imagem era, então, superfície; palavras e fala eram interioridade e profundidade. As palavras transmitiam a alma interior de homens e mulheres mais do que a mera aparência externa. O divino era, em última instância, impossível de ser representado a não ser por palavras, certamente não pela pintura ou escultura. Isto, pelo menos, era a doutrina protestante de forma geral. Ela variava do ceticismo à hostilidade, à representação visual. A palavra como um testemunho superior do divino se tornou um dos pilares do protestantismo e figuras foram limitadas, removidas ou dessacralizadas. Todo este topos estendido - a superioridade das palavras em detrimento das imagens como testemunhos do caráter, da alma e do divino - ofereceu assim uma forma de 
se evitar a realidade do poder das imagens. Ele teve uma história que terminou com a remoção dos quadros dos templos cristãos e a pintura de suas paredes de branco, como sabemos, ironicamente, pelas espetaculares representações feitas pelos contemporâneos de Rembrandt de interiores de igreja sem pintura alguma, incluindo obras-primas do gênero de Pieter Jansz. Saenredam.

Os ataques aos pôsteres do rei do Barém, tão aparentemente similares aos ataques à xilogravura de Erasmo, são imbricados de outra forma. O impulso de mutilar os pôsteres parece ter sido alimentado por fluxos de antipatia diferentes e mais locais. Aqui o objetivo parece ser menos remover o próprio ou homem ou suprimir sua presença viva do que indicar com esses riscos que ele já era, o tirano já era, ele está fora - o que explica o ataque um pouco menos feroz no rei do que em Erasmo. Este impulso também pode ser tomado como testemunho do medo básico da possibilidade de vida em uma imagem, mas nele há claramente menos ansiedade quanto à vitalidade em potencial do rei ou a inerência de seu corpo na imagem. Os riscos são menos veementes. A razão para a diferença pode ser puramente psicopatológica, mas a motivação para este ataque parece ser menos eliminar o ser corporal do que rasurar sua imagem e anunciar sua irrelevância. A ação adquire a qualidade metafórica básica da imagem.

A distinção entre o ataque à pessoa e o anúncio através da imagem pode ser sutil, mas ela articula silenciosamente a antiga noção romana e bizantina de que o imperador está presente onde sua imagem se encontra; se sua imagem é removida, ele não está mais. É como se aqui esta doutrina fundamental da antiguidade tardia tivesse sido adotada na cultura muçulmana. Esta doutrina é uma faca de dois gumes - por um lado ela evidencia a inerência do corpo na imagem; por outro, ela a nega. Alguém poderia argumentar que os sinais do cancelamento na imagem do rei do Barém (fig. 2) são de fato um ataque implícito à sua pessoa, mas finalmente este é um ataque que parece mais um cancelamento de uma imagem do que de um corpo.

Na verdade, em tais contextos é impossível deixar de observar a resistência profundamente enraizada, repetidamente articulada no Hádice, à representação do corpo vivo e da potencial vivificação contida em todas as imagens. Meros humanos não podem criar um ser vivo; apenas Deus pode. O artista chega ao paraíso e Deus o ordena a respirar vida real na imagem que ele criou; ele faIha e é arrojado de lá. O próprio poeta proibiu sua filha de brincar com bonecas. 
Mesmo nestes pôsteres contemporâneos do rei do Barém, é possível encontrar a confluência habitual de motivações - teológicas, assim como sociais e políticas. Cada uma delas é baseada em constantes psicológicas, como o desejo de eliminar aquilo que é demasiadamente realista, mas cada uma é igualmente inflectida pela circunstância local.

A PORNOGRAFIA, OU SUPOSTA PORNOGRAFIA, CONTINUA A SER UM DOS ALVOS MAIS frequentes da censura. Nela vemos como a incorporação do visual encontra a política e a sociedade, e como a censura se junta à iconoclastia. Há uma multidão de exemplos disto, mais do que poderiam ser mencionados. Genitais são cobertos, corpos nus são vestidos ou simplesmente riscados e mesmo pelos, um indicador comum da sensualidade desde os tempos antigos, são removidos. Estátuas antigas de nus são mutiladas ou despedaçadas por serem ídolos pagãos (cf. Buddensieg 1965) ou por serem nus; e o mesmo acontece com suas cópias impressas em épocas posteriores - como, por exemplo, as furiosas linhas de rasura que atravessam gravuras como aquelas da Vênus penteando seus cabelos nua de Giulio Romano (ilustrada em Freedberg 1989, 363 , fig. 167). Em casos como estes, a psicopatologia individual encontra o medo do corpo na imagem, como no caso de Luís de Orléans esfaqueando Leda e o cisne de Correggio, atualmente em Berlim (Freedberg 1985), e na eliminação dos rostos em toda uma série de impressões das fotografias atualmente famosas de Bellocq representando prostituas de New Orleans - nos quais é como se os objetos de desejo devessem ser reduzidos ao anonimato e aquilo que desperta desejos ilícitos ou sensualidade intolerável devesse ser mutilado (cf. particularmente Sontag e Szarkowskin em Bellocq 1996). Isto é ainda mais sedutor porque - especialmente no caso de impressões e fotografias portáteis, mas também na presença pública de quadros em galerias - se trata de um corpo tão disponível e, precisamente por sua substitucionalidade, tão misteriosamente eficaz em despertar desejos.

Um caso, hoje em dia clássico, da confluência de política e pornografia é o da Vênus ao espelho de Velázquez na National Gallery, em Londres. Uma fotografia dramática e ainda chocante mostra os cortes profundos feitos em 1914 por uma apoiadora da campanha sufragista nas costas da figura feminina reclinada (Feedberg 1989, 410-11). Ela é chocante por ainda ter a capacidade de despertar no espectador a sensação de uma resposta física que intensifica o sentido de um ataque direto na carne aparente desta figura pintada. O sentido de insulto ao espectador pode também parecer ainda mais agravado pelo fato de que este é um corpo pintado de forma tão bela. 
Mas aqui a política também se junta a esta preocupação com a pornografia, tanto no mundo antigo quanto nas "guerras culturais" americanas das décadas de 1980 e 1990. Quando Mary Richardson foi presa após ter feito cortes nas costas da Vênus ao espelho em 1914, ela deixou claro que ela o fez para chamar a atenção do público (uma reivindicação frequente dos iconoclastas) para a causa sufragista. Mas quando, quarenta anos depois, Ihe foi perguntada a causa do ataque à pintura, ela disse se sentir ofendida pela forma como "os visitantes do sexo masculino se embasbacavam diante das costas nuas da Vênus o dia todo" (Freedberg 1989, 409-12). Como é frequentemente o caso, a suposta natureza licenciosa de uma pintura se tornou um pretexto útil para um ataque com motivações políticas.

A CADA PONTO NA ANÁLISE DESTE ASSUNTO, É ESSENCIAL EXAMINAR A RELAÇÃO DIALÉTICA entre a resposta subjacente e as necessidades, pretextos e motivações contemporâneos. No caso da iconoclastia e da censura, é fácil ver as similaridades entre as culturas, enquanto os modificadores locais acabam sendo muito mais elusivos.

Quando os Budas gigantes de Bamiã foram explodidos em março de 2001, os rostos foram os primeiros elementos destas estátuas a serem destruídos - embora ainda não se saiba se foram visados deliberadamente ou se foram apenas vítimas de efeitos mais aleatórios das explosões. A possibilidade de visar rostos ou partes específicas deles é muito mais realçada no contexto da ação dos talibãs contra os ídolos de outra religião (uma acusação feita de uma forma ou de outra ao longo da Reforma Cristã, que reaparece a cada vez que o Daesh produz um de seus vídeos mostrando a destruição de imagens) e da supressão dos rostos femininos na sociedade talibã. $\mathrm{O}$ medo subjacente a estas ações continua a ser o medo da vivacidade e da sensualidade, neste caso ainda mais provocado pelo fato de que estas estátuas gigantes de deuses pagãos foram talhadas em rochas demasiadamente imóveis. Quando questionado sobre o propósito destes ataques, um mulá talibã afirmou que elas eram destruídas como ídolos de uma falsa religião; um outro respondeu dizendo que o objetivo era simplesmente obter publicidade para sua causa e o sofrimento de seu povo e suas crianças (e.g. Freedberg 2001; Flood 2002). Os mesmos pretextos de sempre! Não raramente, o iconoclasta sabe exatamente da publicidade que advirá de suas ações e que, quanto mais dramático e famoso o alvo, melhor (cf. Freedberg 1985 para mais exemplos). 
A acusação de que as imagens de uma religião são os ídolos pagãos da outra recorreu sob diversas formas no exemplo pré-moderno clássico da iconoclastia: a guerra contra as imagens religiosas que começou com a Reforma Protestante e atingiu seu apogeu na série de episódios iconoclastas nos Países Baixos entre 1566 e 1575 que marcaram os primeiros anos da revolta contra a Espanha. Imagens eram ídolos porque não mostravam o verdadeiro Deus. Às imagens de valor estético indistinto, assim como às grandes obras de arte, eram atribuídos poderes de salvação e de cura que só poderiam vir da providência divina, e não de meras representações de Deus. Nem Deus, nem Cristo, Virgem ou santo eram inerentes em suas imagens. Para a maioria das religiões protestantes, Deus não poderia ser mostrado em qualquer forma material ou circunscritível.

Para evitar estes e outros perigos (como o uso abusivo de imagens em festivais e outros contextos mais licenciosos), censura e proibição vieram como consequência. Histórias e santos não canônicos foram proibidos. A fusão do primeiro e do segundo mandamento ("Eu sou o Senhor, teu Deus; não terás outras imagens antes de mim... Não farás para ti nenhuma imagem esculpida, nada que se assemelhe a qualquer coisa...") deixava clara a relação entre monoteísmo, idolatria e a fabricação de imagens; sua separação vetava quase absolutamente a figuração (Êxodo 20, 1-3; cf. Stirm 1977, p. 374; Freddberg 1976, p. 123; Freedberg 1989, p. 3). E a maior parte da intervenção dos censores contra a representação do verdadeiro Deus resultou em iconoclastia. Se Deus era mostrado, ele era na maior parte das vezes removido.

Os motivos para a iconoclastia variaram de preocupações teológicas a uma diversidade de outras motivações que poderiam ser extraídas das de caráter teológico, incluindo a acusação de que o dinheiro gasto em monumentos artísticos decorando igrejas e capelas, seja dos ricos ou dos pobres, seria melhor empregado, como o próprio Lutero (e São Bernardo muito antes) disse, nas verdadeiras imagens de Deus, os pobres. A afirmação feita repetidamente pelos teólogos da Reforma de que as imagens eram meros pedaços de madeira morta e pedra e, portanto, ineficazes estava ironicamente em discordância com seus seguidores, que insistiam em destruir imagens, provando efetivamente, como vimos em outros casos, que eles temiam exatamente aquilo que diziam ser inerte ou falso. Por um lado, consequentemente, as ações dos iconoclastas poderiam se passar por bravatas descabidas (por que destruir aquilo que se acredita ser inócuo?). Por outro, esta era uma boa forma de garantirem que as imagens fossem 
vistas e percebidas como verdadeiramente mortas - e consequentemente ineficazes. Este também era, é claro, um meio de garantir que as imagens não estivessem mais disponíveis para a idolatria e todas as práticas supersticiosas que elas acarretavam.

Figura 4

Frans Hogenberg. A revolta iconoclasta de 20 de agosto de 1566, 1583. Água-forte. In: EYTZINGER, Michael.

De leone Belgico. Colônia: Hogenberg.

Fotografia do autor.

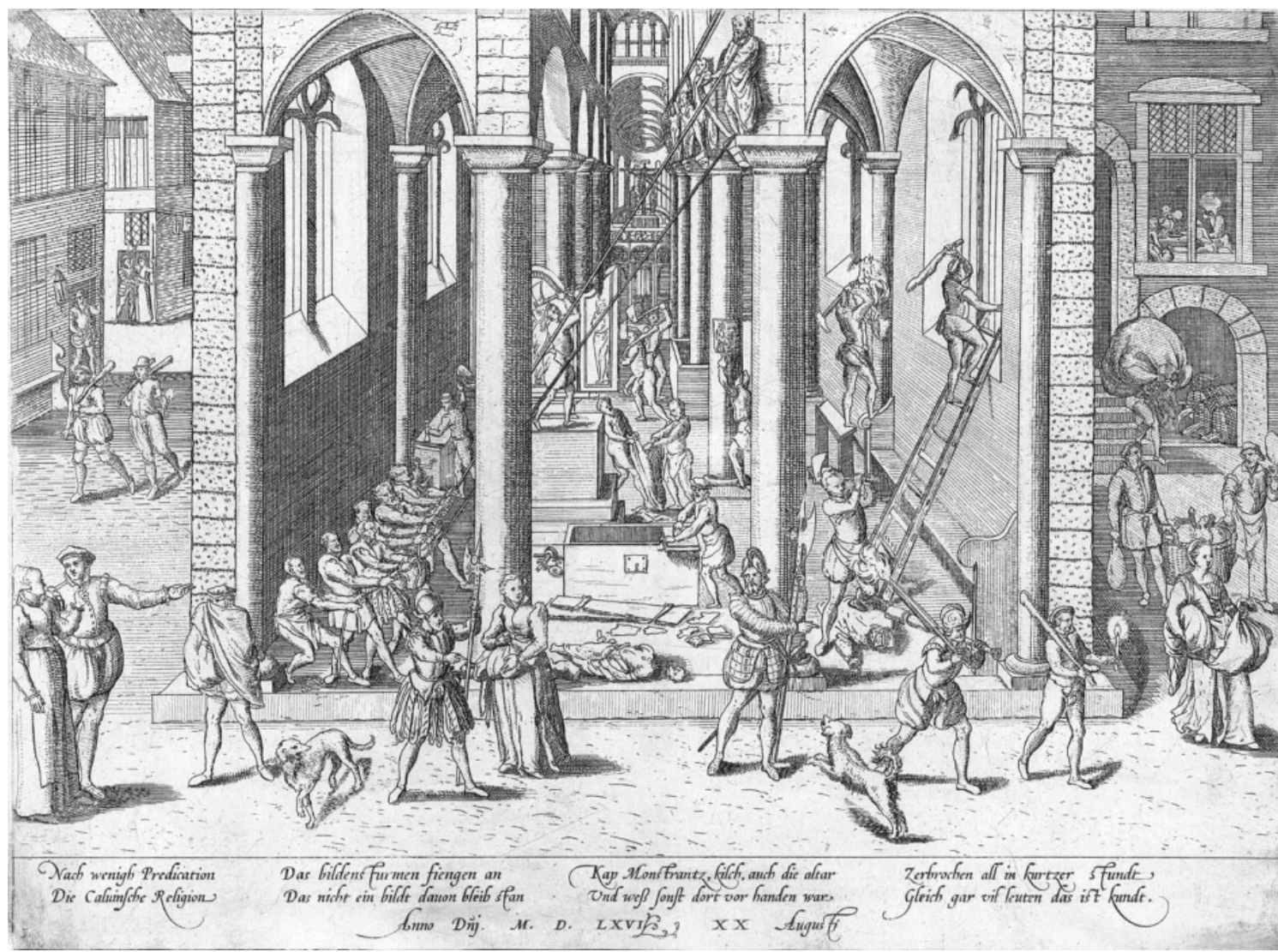

A CRENÇA DE QUE AS IMAGENS SÃO INCORPORADAS, A PROJEÇÃO NA OU A PERCEPÇÃO DA vida nelas, o sentido de inerência do representado na representação, a percepção de animação naquilo que é basicamente estático - tudo isso veio junto no ataque ao corpo da imagem.

Quando amotinadores iconoclastas invadiram a Catedral de Antuérpia na noite de 21 a 22 de agosto de 1566 (ver fig. 4), eles destruíram cada imagem que puderam encontrar, incluindo polípticos nos altares, quadros e esculturas nas paredes, vitrais ou até mesmo iluminuras em livros. Atiraram missais nas fogueiras, arrancaram bordados de casulas e pluviais, e atacaram padres associados a este culto idólatra. O vigor e a violência deste episódio são sintomas extremos das diversas formas pelas quais os motivos teológicos tiravam partido dos medos subjacentes codificados, por assim dizer, no 
misterioso culto das imagens, que, para os protestantes, era vívida e sedutoramente comprovado pelo uso e adoração das imagens dos católicos. Os dois lados se voltaram para semelhanças com evidências dos cultos idólatras das imagens no Antigo Testamento, como nos casos do Baal de Nabucodonosor e das furiosas iconoclastias causadas não tanto por Abraão ou Moisés (nos episódios dos ídolos de Labão e do Bezerro de Ouro, respectivamente), mas pelos reis do Antigo Testamento como Josias e Ezequias (para arruinar os ídolos da Babilônia ou os que eram adorados por seus compatriotas). Além disso, utilizaram o suporte ainda recentemente novo da produção de gravuras para fazer alusões polêmicas a iconoclastias contemporâneas; elas fornecem evidências visuais sugestivas para as constantes de ação e comportamento subjacentes a várias formas de motivação e de movimento.

A gravura da Destruição dos templos de Astarte e Quemós, de Maarten van Heemskerck para a série da História de Josias de 1567, claramente buscava aludir às discussões contemporâneas sobre a adoração das imagens idóla-

Figura 5

Phillips Galle segundo Maarten van Heemskerck. A destru-

ição dos templos de Astarte e Quemós, p.5 da série $A$ história de Josias, 1569. Gravura. Fotografia do autor.

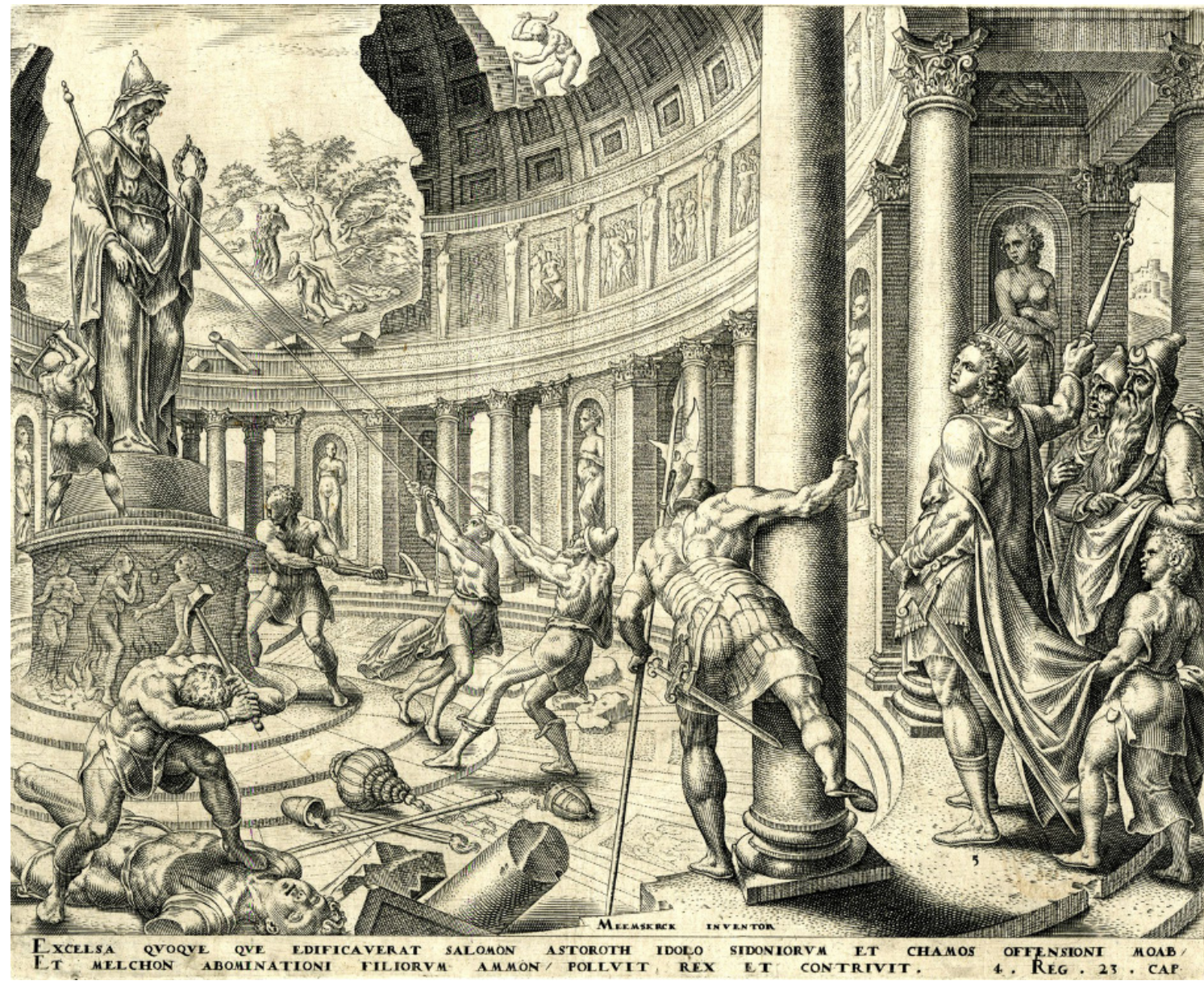


tras, ou mesmo da própria iconoclastia. ${ }^{1}$ Ela mostrava imagens altas e fora de alcance sendo puxadas para baixo por pares de cordas, de uma forma que tanto refletia as ações iconoclastas da época (ver fig. 5; e também Freedberg 1976, 1986)2 quanto antecipava o mesmo método de remover de monumentos modernos - como na remoção da estátua equestre do Xá em Teerã em 1980 (ilustrada em Freedberg 1989, p. 391, fig. 179) e das estátuas de Lênin em toda a Europa oriental no começo da década de 1990. Nestes casos, é claro, a motivação principal era diferente: as imagens deviam ser removidas porque o líder devia ser removido; as imagens não podiam mais estar presentes porque o líder não estava mais presente. $\mathrm{O}$ mais impressionante, no entanto, é a persistência das mesmas formas destas ações para diferentes motivações e objetivos.

Figura 6

Philips Galle segundo Maarten van Heemskerck. A destruição de Bel, p. 6 da série A história de Bel e o dragão,

1564, publicada em 1565. Gravura. Fotografia do autor.

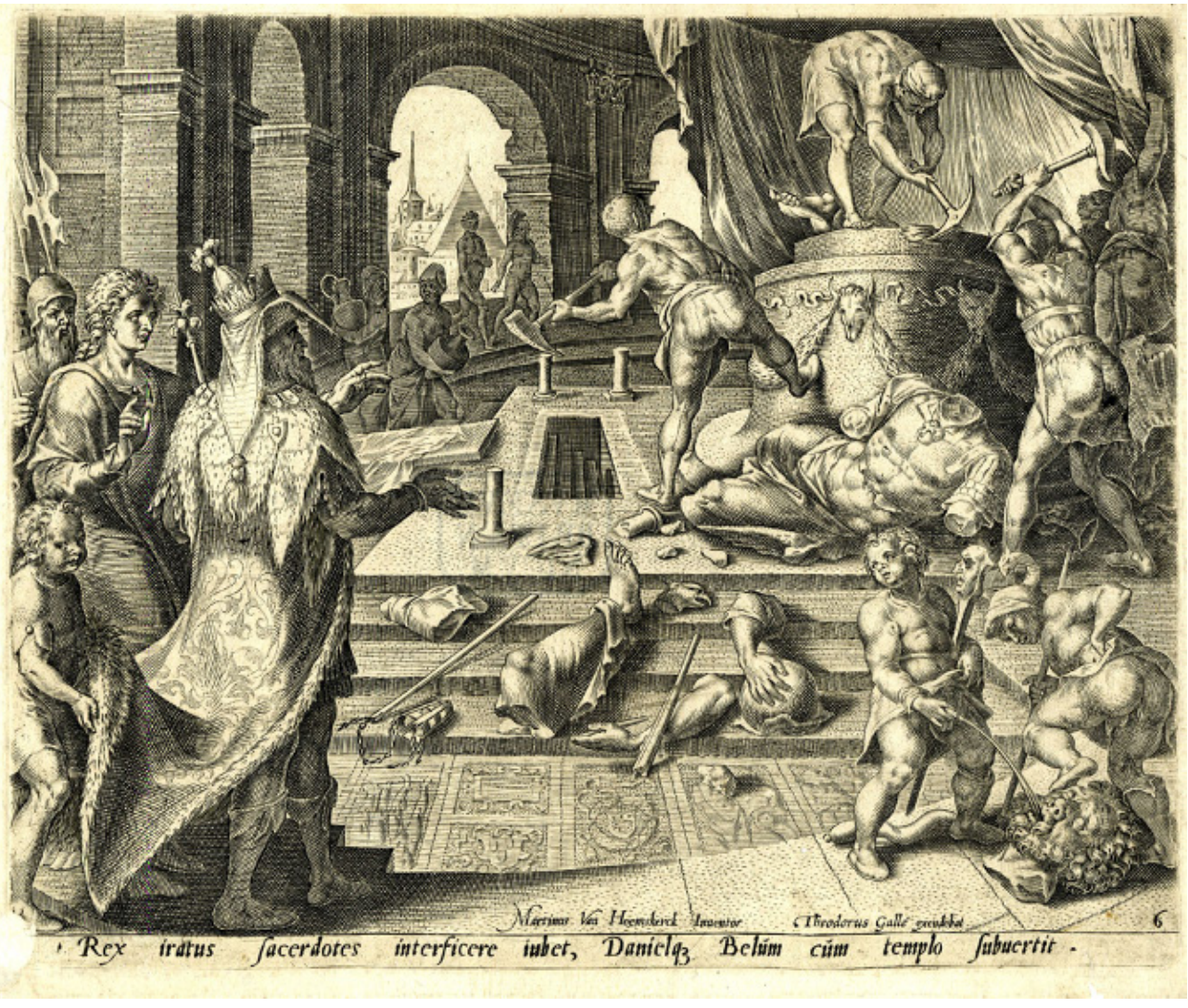

1 Da mesma forma que em uma série similarmente interessante mostrando a destruição dos ídolos organizada pela rainha Atalia, ilustrada em Saunder (1978-9, figs. 7-10).

2 As semelhanças destas ações ao longo deste período são facilmente percebidas na comparação destas ilustrações com a gravura mais ou menos contemporânea de Frans Hogenborg no De Leone Belgico, de Michael Aitzinger em 1583, representando a destruição de imagens na Catedral da Antuérpia em 1566, e com gravuras posteriores de Frans Luyken. 
O levantar de um martelo ou de uma picareta para atingir os pedestais das estátuas ou para derrubá-las pode ser visto em ações musculares quase inteiramente idênticas nas gravuras do século dezesseis e nas fotografias contemporâneas. Excelentes exemplos podem ser encontrados na gravura da Destruição de Bel (fig. 6), de Maarten van Heemskerck para a série de Bel e o dragão, e em uma fotografia da Reuters de uma estátua do líder iraquiano Saddam Hussein sendo despedaçada na Praça Firdos em Bagdá em 2003. Nestas aparentes continuidades, é essencial reconhecer o número relativamente limitado das maneiras como os humanos podem levantar um martelo para atingir, uma faca para atacar, uma corda para derrubar estátuas e assim por diante.

A remoção da estátua de Saddam Hussein na Praça Firdos fornece alguns exemplos destas semelhanças e limitações - assim como uma advertência significativa, ainda que óbvia. Muitas das formas de hostilidade perpetradas a esta estátua parecem ser encontradas em representações mais antigas da remoção e derrubada da estátua de um tirano. Se bater as solas dos sapatos em seu rosto (com a enorme cabeça agora no chão) reflete uma forma de insulto particularmente islâmica (as solas do sapato na pele, no rosto ou apenas na foto de alguém), uma das mais admiráveis recorrências aqui é a forma como um jovem urina na boca da estátua - a expressão máxima de desdenho (e possivelmente também da inutilidade das palavras que saíram da boca de Saddam). Praticamente a mesma forma de insulto é visitada por um putto na cabeça quebrada da estátua antiga no chão na gravura de 1565 de Maarten van Heemsckerck da Destruição de Bel para a série da História de Bel e do dragão (fig. 6). Ele o faz porque as esculturas haviam sido por muito tempo percebidas como insulto à Cristandade, e não tanto porque fossem figuras idólatras ou licenciosas, mas porque eram imagens de deuses pagãos (Buddensieg 1965).

Se o contexto sociocultural pode determinar as formas de tratamento, a variedade da ação destrutiva é limitada pelos simples limites da possibilidade corporal (como no caso das mãos levantadas para golpear com o punho ou martelo). Repetidamente, a modulação contextual encontra os limites da possibilidade de movimento corporal e propriocepção - o que explica a aparente recorrência de fórmulas gestuais para ações e emoções ao longo da história.

Um dos problemas recorrentes na análise de diversos episódios iconoclastas é a relação entre ataque deliberado e espontâneo, seja no caso de indivíduos 
ou de turbas. Quando escrevi um artigo para o Wall Street Journal sobre a destruição da estátua de Hussein na Praça Firdos em abril de 2003, eu o baseei nos relatos e fotografias publicados nos dias que se sucederam àquele acontecimento e fiz o recorte da minha discussão em termos tanto dos sentimentos aparentemente espontâneos de antipatia contra Saddam e sua imagem, quanto da resistência muçulmana à figuração, particularmente a de um líder odiado. Poucos dias depois, contudo, ficou claro que as fotos publicadas naquele jornal haviam sido cortadas de forma a eliminar a presença dos marinheiros americanos na cena, para impedir que seu papel ativo na organização daqueles ataques estragassem o efeito de antipatia popular e espontânea contra Saddam. Sua presença absolutamente aberta no local foi deliberadamente tirada de cena (tanto no sentido literal quanto figurado). Esta foi uma perfeita ilustração da máxima de Judith Butler segundo a qual "Fazer um recorte pressupõe decisões ou práticas que deixam perdas substanciais fora dele" (Butler 2009, p. 75). Eu havia feito o recorte de minha discussão com base no recorte deliberadamente enganador de uma cena.

Na medida em que as imagens se tornam mais amplamente disponíveis, mais facilmente reprodutíveis e mais acessíveis do que nunca, seu poder cresce e a iconoclastia se torna ainda mais frequente e difundida. O Daesh hoje em dia utiliza as imagens com máxima eficácia, sabendo bem que o horror das execuções que retratam atingirá ampla disseminação. Ao mesmo tempo, seus soldados se empenham na destruição de grandes obras de arte da Mesopotâmia - de Ninrude e Mossul a Palmira e além - para ganhar ainda mais publicidade para sua causa. Eles se valem de pretextos teológicos para suas ações (estes são os ídolos de religiões sem Deus, eles testemunham a idolatria do passado e assim por diante), mas sabem que, sejam elas disseminadas ou eliminadas, tanto as imagens quanto sua destruição têm a capacidade de transmitir mensagens fundadas na incitação das fantasias e medos mais profundos.

Deixe-me concluir com um episódio sul-africano recente que oferece um exemplo dramático e instrutivo do quão rapidamente a censura oficial pode se tornar, ou ser manipulada a se tornar, iconoclastia pública. Este é um exemplo que chama atenção para várias das questões que discutimos até aqui, inclusive a dificuldade de se desvendar as relações entre atos planejados e espontâneos, insulto e liberdade de expressão, autoctonia e constitucionalidade, e talvez a dificuldade em se dissociar a pornografia da política. Ele ilustra vividamente por que o medo da arte é sempre fundado no poder das imagens ou nas imagens metafísicas transmitidas pelo estilo ou conteúdo. 
Em 2012, Brett Murray pintou um retrato do presidente sul-africano, Jacob Zuma. Esta era uma imagem forte de qualquer forma, pintada predominantemente em vermelho, amarelo e preto não matizados, mostrando Zuma marchando para frente com o braço direito levantado e seu pênis para fora de suas calças abertas. Tendo como referência o famoso pôster de Lênin de 1967 de Victor Ivanov, o retrato era claramente uma obra ferozmente satírica aludindo ao conhecido apetite sexual de Zuma, suas várias esposas e os diversos escândalos sexuais nos quais ele estava envolvido, incluindo o suposto estupro da filha de um amigo. ${ }^{3}$ A pintura foi intitulada $A$ lança da África, abertamente em referência não apenas à sua dimensão sexual explícita, mas também como trocadilho ao Umkhonto we Sizwe, Lança da Nação, nome do grupo armado do partido Congresso Nacional Africano (ANC) durante seu longo período de exílio. Em qualquer medida, esta era uma imagem incendiária.

Como era de se prever, Zuma, sua família e posteriormente o ANC abriram processos na tentativa de proibir A lança de ser reproduzida na imprensa e de ser exposta na Goodman Gallery em Johannesburgo. As ações judiciais eram baseadas em grande parte no suposto insulto à dignidade presidencial, o que, como era frequentemente argumentado, desrespeitava o comprometimento firme e declarado da nova constituição sul-africana com a liberdade de expressão artística. A resposta dos aliados políticos e ministros de Zuma, e até mesmo do próprio ministro da justiça, era de que a pintura apresentava uma imagem tão ofensiva que sequer era arte.

Outras ações já haviam sido movidas contra o cartunista político Zapiro (Jonathan Shapiro), em um esforço para suprimir muitos de seus cartuns recentes satirizando os apetites sexuais de Zuma, em particular sua famosa negação para uma pergunta sobre como ele teria conseguido evitar a AIDS (um assunto sensível na África do Sul), à qual ele respondeu que sempre tomava banho depois de ter relações. Um destes cartuns mostrava um chuveiro crescendo entre suas pernas no lugar do pênis; outros dois o mostravam, ainda mais amargamente, com o chuveiro crescendo em sua cabeça, prestes a atacar a "Senhora Justiça" deitada, de olhos vendados e presa ao chão pelos representantes do ANC e dos sindicatos, com a ba-

3 O retrato também pode ter tido como referência a famosa imagem do Homem com terno de poliéster de Robert Mapplethorpe, que foi uma das diversas obras deste artista a terem sido alvos de repetidos esforços de supressão durante as guerras de cultura americanas do início dos anos 1990 . 
lança da justiça a seu lado - em outras palavras, a justiça incorporada na constituição sul-africana do pós-apartheid. "Vá em frente, chefe", diz um de seus apoiadores em um destes cartuns; no outro, Zuma responde "Mas antes de começar, quero apenas dizer o quanto a respeitamos", logo antes de estuprá-la. Não é muito surpreendente que o ANC tenha se esforçado em banir a circulação e a exposição pública de tais imagens.

Apesar dos protestos e do processo iminente, o quadro foi exposto na Goodman Gallery. Reproduções digitais da imagem começaram a ser distribuídas pelas pessoas em seus telefones, espalhando-as como fogo selvagem no país. A obra foi reproduzida no City Press, a despeito das ameaças ao editor e de outras injunções por parte do ANC, de Zuma e de sua família. As acusações de insultos à dignidade presidencial se multiplicaram. Naquele momento, para meu espanto e de muitos outros, um grande número de mulheres se reuniu em apoio a um homem que - para dizer o mínimo - tinha insultado sua própria dignidade, repetidamente. Seu comportamento sexual e antifeminismo eram bem conhecidos em toda a África do Sul. Ainda assim, mulheres fizeram manifestação em seu favor e seguiram outra via. "Dizemos não à expressão artística abusiva”, dizia um pôster; "O presidente Zuma tem direito a Dignidade Humana e Privacidade", dizia outro, refletindo sobre a discussão pública acalorada que acontecia naquele momento sobre se a licença artística poderia ser permitida a abusar do presidente.

Mas como explicar estes protestos contra a pintura vindos precisamente das pessoas de quem se teria esperado legitimamente a sua aprovação? É claro que a exposição do órgão masculino poderia ser vista como indecente, mas se esperava ao menos que o propósito da sátira fosse levado em consideração.

Embora muito desta controvérsia parecesse revolver acerca da relativa priorização da dignidade presidencial e da liberdade de expressão garantida constitucionalmente, questões muito mais profundas estavam claramente em jogo. Primeiramente, todo este caso aconteceu durante o período de eleições (ou reeleição) do líder do ANC, que se tornaria então efetivamente presidente da África do Sul novamente. Nesta conjuntura crítica, a controvérsia sobre a pintura de Bill Murray permitiu que o ANC organizasse manifestações em apoio ao próprio Zuma, nas quais a suposta pornografia se tornou ainda mais profundamente um assunto de Realpolitik. 
$\mathrm{Na}$ época deste episódio, eu me encontrava por acaso na África do Sul, de volta ao lugar onde nasci depois de ter me ausentado por mais de 40 anos. Eu estava enfurecido com os esforços do ANC em fechar o City Press e impedir que a pintura fosse vista publicamente ou exposta na galeria. Então alguns de meus antigos amigos de escola, ainda membros do ANC ou do Partido Comunista Sul-Africano, rejeitaram indignadamente a minha indignação, com base no que sentiam ser uma alusão na pintura de Murray à antiga calúnia sobre apetite e proezas sexuais superiores do homem negro. Apenas por estes motivos, eles - e muitos outros - sentiam que o quadro não merecia o opróbrio que tinha incitado, mas também que deveria ser destruído. Muitos colunistas de esquerda, tanto brancos quanto negros, escreveram contra o que parecia ser o sentimento da maioria, precisamente por estes motivos (Schutte 2012). Em um primeiro olhar, o meu posicionamento - e o de todos os liberais - era perfeitamente politicamente correto; sob este outro - para mim inesperado - ponto de vista, ele claramente era bastante politicamente incorreto.

Foi neste contexto do clichê sobre a sexualidade negra que as manifestantes mulheres ganharam uma nova motivação mais profunda: "Poligamia é a minha cultura, assim como o aborto e a sodomia é a sua" dizia um dos pôsteres. Usando o pretexto da antiga calúnia, o ANC organizou uma ampla oposição feminina ao quadro, em favor de um homem que dificilmente poderia ser descrito em suas relações sexuais com mulheres como qualquer coisa senão como sexista. Mas uma conclusão do tipo poderia agora ser rejeitada como um conjunto de preconceitos típicos de um homem branco.

Havia ainda outra ironia no encontro da política de gênero com o uso da sátira sexual para propósitos políticos em uma maneira que não poderia ter sido prevista. Zuma e seu governo planejavam reinstaurar os tribunais tribais. Estava claro que em diversos aspectos cruciais isto iria contra a nova constituição nacional da qual os sul-africanos tinham então tanto orgulho. Entre as questões em jogo, como muitas feministas sul-africanas de todas as raças observaram, havia o fato de que os direitos das mulheres eram muito mais restritos nos tribunais tribais do que nos da constituição, e de que os juízes destes tribunais eram muito mais propensos a tomar decisões de um ponto de vista predominantemente masculino e tradicional em questões de sexo e gênero. $E$, ainda assim, as mulheres que protestaram contra o quadro o fizeram em defesa de um homem cuja vida pessoa não demonstrava nada mais do que desdenho pelas mulheres e que, em sua vida política, estava 
prestes a restabelecer tribunais que subverteriam exatamente alguns dos direitos femininos assegurados pela nova constituição. A ironia estava clara para todos.

Alguns meses antes que a controvérsia estourasse, eu havia sido convidado a dar uma palestra sobre iconoclastia e censura na Universidade de Stellenbosch. A ocasião para o convite era a perplexidade da faculdade de belas artes sobre diversos ataques recentes a obras de arte contemporânea públicas, sobretudo esculturas, em várias partes da cidade. Sua surpresa era ainda maior porque muitos estudantes haviam escrito à imprensa em apoio aos ataques, em parte sob a justificativa de que o lugar das obras de arte era em museus e galerias, e não no espaço público. Seu medo da arte se manifestava no desejo de contê-la nos limites seguros do espaço privado ou institucional.

Até 4 de maio de 2012, data da palestra, a controvérsia sobre A lança da África estava a pleno vapor. Não tive então outra opção a não ser concluir minha fala com uma breve discussão sobre o tema, e alertei que os meus estudos sobre censura sugeriam que casos como este frequentemente resultavam em plenos ataques à arte.

Assim que me sentei, uma estudante se levantou e, sacudindo seu telefone, anunciam "O quadro acabou de ser atacado". As fotos em seu telefone celular coincidiam com as diversas imagens publicadas mais tarde. Um homem branco bem vestido, subsequentemente identificado como Barend La Grange, de 59 anos, entrara na galeria com um pote de tinta e pincel, colocado uma grande cruz vermelha sobre o pênis de Zuma e, em seguida, sobre seu rosto; mal havia ele terminado, quando um homem negro muito mais jovem, Lowie Mbokela, entrou e jogou uma lata inteira de tinta preta sobre a obra. Ela foi assim efetivamente destruída, embora na verdade o habitual tenha acontecido - a obliteração da parte do corpo ofensiva, primeiro; a eliminação do rosto, em segundo lugar; e, por último, o ataque violento ao corpo inteiro. O homem branco foi gentilmente detido; o homem negro como muitos observaram - foi rendido com violência no chão, algemado e conduzido sob custódia.

Embora cada um dos agressores tenha dado seus próprios motivos para atacarem a pintura (os de La Grange estavam relacionados à sua vergonha pelo insulto ao presidente negro; os de Mabokela à sua irritação com a qualidade inferior da obra enquanto arte), nunca ficou claro se eles agiram por 
conta própria ou se eles também haviam sido encarregados de fazer um ataque tão público - e publicamente registrado - a uma obra de arte tão insultante e pornográfica (se é que poderia ser chamada de obra de arte, muitos disseram).

A Goodman Galery fechou suas portas por um tempo, mas a ação judicial teve continuidade. Pouco tempos depois de tomar a palavra, o advogado do ANC se pôs a chorar enquanto defendia o caso. O Comitê dos Jovens Comunistas anunciou que a desfiguração do retrato era justiça popular e que os agressores deveriam receber a Ordem de Ikhamanga, normalmente atribuída por excelência nas artes, jornalismo e no esporte, por bravura. Devagar, tanto o City Press quanto a galeria cederam. A 28 de maio de 2012, a editora do jornal removeu a pintura da página do periódico na internet, pediu desculpas a uma das filhas de Zuma e escreveu: "a lança foi retirada. Por zelo e como um ato de reconciliação para ajudar a superar um momento difícil, decidi retirar a imagem". O poder das imagens dificilmente poderia ser manifesto de forma mais clara. "Quando publicamos uma crítica de arte contendo uma reprodução da Lança, eu não poderia ter previsto que isto viraria uma bola de neve culminando em um momento de tanta raiva e dor", ela continuou. "É claro que a imagem também está sendo removida por medo... A atmosfera é como um barril de pólvora: cópias do City Press estavam em chamas sábado passado. Eu não quero mais jornais queimados com raiva...". E assim por diante. ${ }^{4}$

O secretário geral do ANC e o proprietário da Goodman Gallery se reuniram para anunciar que o ANC desistiria da causa judicial se a galeria concordasse em não expor novamente $A$ lança. Em uma coletiva de imprensa no dia 30 de maio, a galeria e o ANC anunciaram um acordo que incluiria também a remoção da pintura da página da galeria na internet. O caso do ANC contra a galeria e o pedido de boicote contra o City Press foram descartados, e a galeria negou subsequentemente que tivesse concordado em remover a imagem. Também no dia 30 de maio, o Painel de Filmes e Publicações rejeitou todos os argumentos jurídicos e alterou a classificação indicativa da pintura para acima de 16 anos.

4 O pedido de desculpas original de Ferial Haffajee não está mais disponível na página do City Press, mas é citado em diversas fontes, como Waal (2012). 
O caso de difamação contra Zapiro continuou por mais alguns meses e esmoreceu com a indenização reduzida de cinco milhões de randes para zero, mas com a requisição de que o cartum fosse acompanhado de alerta de recomendação.

"O caso foi bom para os negócios da galeria", observou The Guardian (Smith 2012). O quanto o valor da obra deve subir, mesmo em seu estado danificado, ainda não se sabe.

A pintura não pode mais ser vista em sua condição original. Quando fui convidado a escrever um artigo sobre a destruição da pintura na revista de arte mais importante - e liberal - da África do Sul (Freedberg 2012), eu não fui autorizado a publicar a versão original da imagem sob a justificativa de que o governo havia proibido sua circulação e publicação.

O destino da Lança faz parte de uma longa história de antipatia e medo das imagens. Ele também é um testemunho claro do reconhecimento de seus poderes. As antigas emoções por ele despertadas mobilizaram milhares de pessoas. Mas em uma inversão do habitual ataque a uma imagem como ataque à pessoa representada, o ataque metafórico a Zuma (sob a forma de pintura) levou a um ataque à pintura em si. A inversão adicional é que os agressores não agiram por antipatia ao tema da pintura, mas em seu apoio e - contra a própria arte e a liberdade de expressão criativa.

Este episódio demonstra claramente a oscilação entre as constâncias subjacentes ao medo da arte e as diferenças que emergem das formas como o medo é modulado e explorado sob circunstâncias e pressões sociopolíticas específicas. Contudo, cada um dos vários motivos para censura e iconoclastia é um testemunho, acima de tudo, da impossibilidade de escapar deles.

\section{Referências}

ALBERTI, Leon Battista. On Painting. Revised edition. New Haven: Yale University Press, 1966.

BARBER, Tabitha; BOLDRICK, Stacy. Art under Attack : Histories of British Iconoclasm. Londres: Tate Publishing, 2012. 
BELLOCQ E. J, et al. Belloca : Photographs from Storyville, the Red-Light District of New Orleans. Londres: J. Cape, 1996.

BLUNT, Anthony. Artistic Theory in Italy, 1450-1600. Oxford: Clarendon Press, 1962.

BOLTON, Richard. Culture Wars : Documents from the Recent Controversies in the Arts. Nova York: New Press, 1992.

BUDDENSIEG, T. "Gregory the Great, the Destroyer of Pagan Idols: The History of a Legend Concerning the Decline of Ancient Art and Literature.", in: Journal of the Warburg and Courtauld Institutes 28: 28-44. 1965.

BUTLER, J. "Torture and the Ethics of Photography: Thinking with Sontag.", in: BUTLER, Judith (org.). Frames of War: When Is Life Grievable?, pp. 63-100. Nova York: Verso, 2009.

COELEN, Peter van der; BOL, Marjolijn. Images of Erasmus. Rotterdam: Museum Boijmans van Beuningen, 2008.

DE WAAL, Mandy. "City Press Buckles to ANC Demands-and Threats", in: Daily Maverick (South Africa), 29 de maio de 2012.

DODD, A. Spear and Loathing: The Image That Undid Us. Johannesburgo: Parktown Publishers (Mampoer Shorts), 2012.

DUPEUX, Cécile; JEZLER, Peter; WIRTH, Jean. Bildersturm: Wahnsinn Oder Gottes Wille? Mu“nchen: W. Fink, 2000.

ELSNER, Jas'. "Iconoclasm as Discourse: From Antiquity to Byzantium”, in: The Art Bulletin 94 (3): 368-94, 2012.

EMMENS, Jan A. "Ay Rembrant, Maal Cornelis Stem”, in: Nederlands Kunsthistorisch Jaarboek 7, no: 133-65, 1956.

FLOOD, Finbarr Barry. "Between Cult and Culture: Bamiyan, Islamic Iconoclasm, and the Museum", in: The Art Bulletin 84 (4): 641-59. 2002.

FLOOD, Finbarr Barry; STROTHER, Zoe“ Sara. "Between Creation and Destruction", in: Res, vol. 48, novembro: 5-10, 2005. 
FREEDBERG, David. "The Structure of Byzantine and European Iconoclasm" in: Iconoclasm, BRYER Anthony; HERRIN, Judith (org.), pp. 165-177. Birmingham: The University of Birmingham, 1977.

. "Iconoclasm and Painting in the Netherlands, 1566-1609." Tese de doutorado, University of Oxford, 1972.

. "The Problem of Images in Northern Europe and Its Repercussions in the Netherlands" in: Hafnia. Copenhagen Papers in the History of Art (Proceedings of the 7th International Colloquium in the History of Art), pp. 25-45, 1976a.

. "The Representation of Martyrdoms During the Early Counter-Reformation in Antwerp", in: Burlington Magazine 118 (872-873): 128-38, 1976b.

. Iconoclasts and Their Motives. The Second Horst Gerson Memorial Lecture, University of Groningen. Maarssen/Montclair, N J: Gary Schwartz/ Abner Schram, 1985.

. The Power of Images: Studies in the History and Theory of Response. Chicago and Londres: University of Chicago Press, 1989.

. "The Power of Wood and Stone [on Taliban Destruction of Art]", in: The Washington Post, Outlook, 25 de março de 2001.

"The Hidden God: Image and Interdiction in the Netherlands in the Sixteenth Century." Art History, vol. V, 2 : 133-53, 1982.

. “De Kunst En De Beeldenstorm, 1525-1580. De Noordelijke, Nederlanden / Art and Iconoclasm, 1525-1580. The Case of the North Netherlands", in: Kunst Voor De Beeldenstorm. Noordnederlandse Kunst 1525-1580, KOK, J. P. Filedt et al., pp. 39-84. Amsterdam: Rijksmuseum, 1986.

. "Censorship Revisited”, in: Res, vol. 21, n.: 5-11, 1992.

. "Damnatio Memoriae: Why Mobs Pull Down Statues", in: Wall Street Journal-Eastern Edition, 16 de abril de 2003.

"The Case of the Spear." Art South Africa 11(1): 36-41, 2012. 
FREEDBERG, D.; GALLESE, V. "Motion, Emotion and Empathy in

Esthetic Experience", in: Trends Cogn Sci 11 (5): 197-203, 2007.

KIRCHGAESSNER, Stephanie. "Rome spares Iranian president's blushes by covering nude statues", in: The Guardian, 26 de janeiro de 2016. Disponível em:

http://www.theguardian.com/world/2016/jan/26/rome-spares-iranian-presidents-blushes-covering-nude-statues. KEYSERS, C.; WICKER, B.; GAZZOLA V.; ANTON, J. L.; FOGASSI, L.; GALLESE,V. "A Touching Sight: SII/Pv Activation During the Observation and Experience of Touch." Neuron, vol. 42 (2): 335-46, 2004.

KLOEK, W. T; KOK, J. P. Filedt. Kunst Voor De Beeldenstorm: Noordnederlandse Kunst 1525-1580. 2 vols. Amsterdam/'s-Gravenhage: Rijksmuseum/ Staatsuitgeverij, 1986.

LATOUR, Bruno; WEIBEL, Peter. Iconoclash. Karlsruhe: Zentrum fu " $r$ Kunst und Medientechnologie, 2002.

PRODI, Paolo. Ricerca Sulla Teorica Delle Arti Figurative Nella Riforma Cattolica. Rapporti/Reprint. Bologna: Nuova Alfa, 1984.

SAUNDERS, E. "A Commentary on Iconoclasm in Several Print Series by Maarten Van Heemskerck", in: Simiolus: Netherlands Quarterly for the History of Art 10 (2): 59-83, 1978-79. SBRISCIA FIORETTI, B.; BERCHIO, C.; FREEDBERG, D.; GALLESE,V; UMILTÀ, M. A. "ERP Modulation During Observation of Abstract Paintings by Franz Kline”, in: PLoS ONE 8 (10): e75241, 2013

SCHUTTE, Gillian. "The President's Penis", in: SACSIS (South African Civil Society Information Service), 21 de maio de 2012.

SMITH, David. "Jacob Zuma Goes to Court over Painting Depicting His Genitals", in: The Guardian, 21 de maio de 2012.

UMILTÀ, M. A., BERCHIO C.; SESTITO, M; FREEDBERG, D; GALLESE, D. 
"Abstract Art and Cortical Motor Activation: An EEG Study", in: Frontiers in Human Neuroscience 6 (311): 1-9, 2012.

UMILTÀ, M. A.; KOHLER, E; GALLESE, V.; FOGASSI, L.; FADIGA, L; KEYSERS, C.; RIZZOLATTI, G. "I Know What You Are Doing. A Neuro- physiological Study." Neuron 31(1): 155-65. 2001.

Recebido em 10 de setembro de 2021 e aceito em 28 de outubro de 2021. 